\title{
THE NUMERICAL ANALYSIS OF THERMAL PROCESSES IN A TWIN-SCREW ELECTROMECHANICAL HYDROLYSER FOR POULTRY BY-PRODUCTS PROCESSING
}

\author{
S. I. Kovalchuk ${ }^{1}$, N. N. Zablodskiy ${ }^{1}$, A. V. Zhyltsov ${ }^{1}$, R. M. Chuenko ${ }^{1}$, V. Y. Gritsyuk ${ }^{2}$ \\ ${ }^{I}$ The National University of Life and Environmental Sciences of Ukraine \\ ${ }^{2}$ Kharkiv National University of Radio Electronics
}

\begin{abstract}
A spatial image of temperature was obtained by mathematical modelling of the physics of electromagnetic fields, heat transfer in solids and multiphysics communication - electromagnetic heating in the frequency-transition region of the study. The model is built according to the finite element method. The simulation results are presented in the form of a three-dimensional image of the magnetic field distribution density, spatial images of temperature, the volumetric density of electrical losses, graphical dependences of temperature and current density.
\end{abstract}

Keywords: keratin raw material, hydrothermal hydrolysis, Maxwell's equation, Fourier's law, magnetic induction, thermal calculation

\section{Introduction}

The poultry industry plays an important role in meeting the growing demand for food production, but its activities exacerbate the environmental problem. The industry produces about 12 million tons of feathers annually [1]. The feathers as a by-product of industry are a mass mixed with blood, this waste can contain a significant viral load [2], their accumulation leads to environmental pollution, endangering human and animal health.

As a rule, poultry waste is taken to landfills or incinerated. Only a small part of downy feather waste can be recycled. Feather flour as a product of downy feather waste processing is a valuable raw material in the medical, pharmaceutical, cosmetic and biotechnological industries [3]. The products of these industries are innovative, but use feather flour in small quantities or have a narrow range of practical applications [4], which is mainly due to the complexity of feathers processing. Feathers are a type of protein material and consist of $90 \%$ keratin. Keratin is a structural protein that is distinguished by its resistance to various physical and chemical factors [5]. Keratin extraction is possible only under the conditions of the destruction of disulfide covalent bonds and hydrogen bonds in the structure of the material. The main methods of extracting keratin from downy feather waste are hydrothermal, acid, alkaline and enzymatic hydrolysis. One of the most efficient methods of processing down and feather waste on an industrial scale is the method of hydrothermal hydrolysis. The hydrothermal hydrolysis process is the conversion of biomass under pressure at moderate temperatures of $180-230{ }^{\circ} \mathrm{C}$ through a series of reac-

(C) Kovalchuk S. I., Zablodskiy N. N., Zhyltsov A. V., Chuenko R. M., Gritsyuk V. Y., 2021 tions of hydrolysis, condensation, decarboxylation and dehydration [6]. Water acts as a green solvent because it is cheap, affordable and non-toxic. Under conditions of hydrothermal hydrolysis, water is in a subcritical liquid phase, which is characterized by increased solubility of organic substances.

Increasingly, hydrothermal hydrolysis of poultry by-products is performed in screw converters. The use of a screw converter is attractive for its versatility in the processing of various materials, regardless of the pace of the technological process. Screw converter is an electromechanical device with multifunctional properties, it is characterized by simplicity of design, and mechanical forces that occur during operation, improve the processes of mixing and heat transfer [7-9]. Among the existing publications, there are many works devoted to the study of thermal processes occurring in screw converters. In [10], studies of the heat transfer effects of the processing material were carried out. It is determined that the heat transfer effect in a twin-screw converter is better than in a single-screw one. Fundamental physical phenomena and interactions between physical movement and chemical reactions in processing raw materials are determined. Recommendations for the design of screw transducers are given. Insufficient attention is paid to the study of the influence of the geometry of the auger blades on the productivity of the output and the quality of raw material processing. Mathematical modelling of the hydrodynamics processes, heat transfer and chemical reactions of particles in a twin-screw converter was performed in [11]. The publication uses the method of discrete elements to build a mathematical model. It is determined that the process of biomass processing in the twin-screw mechanism is significantly influenced by the reaction heat parameter in the kinetic model. The disadvantages of the pro- 
posed model include the complexity of use, which is due to the need to carefully calibrate the parameter of the heat of reaction to improve the kinetic model. In [12], the inefficiency of the screw converter in the area of initial mixing was revealed, which leads to uneven heat transfer in suboptimal conditions. A mathematical model is constructed that eliminates these inefficiencies and accordingly increases the initial average heat transfer coefficient in comparison with the initial design of the screw converter. Problems of high energy costs for processing in the screw electromechanical converter are solved in [13]. The mathematical research is carried out in the work and the analysis of the received data is executed. Graphical dependences of power and energy parameters of technical research system are constructed. Publications [10-13] comprehensively consider the thermal processes that occur in screw converters in the process of processing various raw materials, but the problem of high energy costs remains unsolved. The development of energy-saving technologies is directly related to increasing the efficiency of individual elements of the system, integrating the functional features of the system in one device and the use of dissipative energy. Since the increase in efficiency under the condition of achieving a certain level of system optimization is achieved by developing new active and insulating materials, the methods of its increase are limited. For technological systems that combine the processes of heat transfer and mixing of materials, the method of dissipative energy should be considered the most effective.

Energy-efficient processing of poultry byproducts under the conditions of use the dissipative energy can be carried out in a twin-screw electromechanical hydrolyser proposed in this work, Fig. 1.

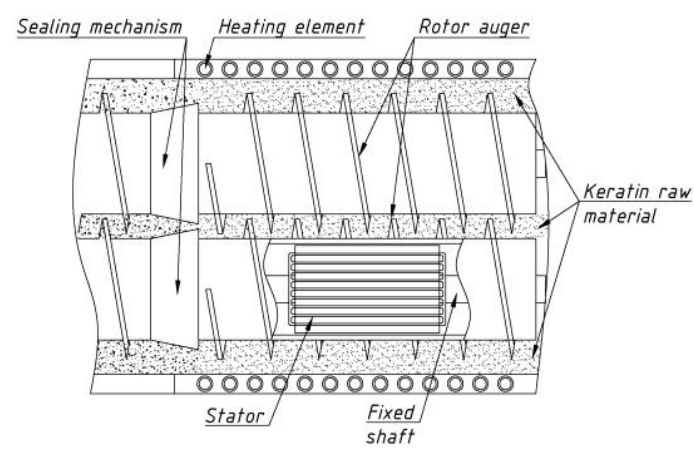

Fig. 1. Twin-screw electromechanical hydrolyser

In such a hydrolyser, the stators placed on a common fixed shaft generate counter-directed electromagnetic moments leading the ferromagnetic rotor without the use of a mechanical reducer. The ferromagnetic rotor simultaneously moves, heats, grinds and creates an effect of a rotating magnetic field on the material of processing [14]. The devel- opment of a twin-screw electromechanical hydrolyser with specified parameters requires a detailed analysis of heat transfer parameters. A mathematical model of a multifunctional electromechanical converter with a ferromagnetic rotor, taking into account the full use of dissipative energy, structural, functional and thermal integration was performed in [15]. The study of thermal heating of the device in the environment of bulk material using the software MATLAB Simulink was performed by constructing an equivalent thermal circuit. Graphical dependences of the heating temperature of a multifunctional electromechanical converter as a function of time are obtained. Although the simulation results with high accuracy corresponding to the measurements of the heating temperature performed experimentally, the model does not reveal the full picture of the temperature field but only some average temperature for individual elements of the device. Due to the complexity of the design of the ferromagnetic rotor of a twin-screw electromechanical hydrolyser, it is advisable to have a complete picture of its characteristics at the preliminary design stage. Thus, the work aims to develop a mathematical model of the ferromagnetic rotor of a twin-screw electromechanical hydrolyser for the analysis of thermal processes occurring during its operation.

\section{Mathematical model}

Due to the required accuracy of the design feature and time spent on implementation, the mathematical model of the ferromagnetic rotor of a twinscrew electromechanical hydrolyser is made by the finite element method based on Comsol Multiphysics software. The analysis of the electromagnetic field is based on the system of Maxwell's equations:

$$
\nabla \times H=J
$$

where $H$ - vector of magnetic field strength, $\mathrm{A} / \mathrm{m} ; J$ - current density vector, $\mathrm{A} / \mathrm{m}^{2}$.

$$
B=\nabla \times A
$$

where $B$ - magnetic field density vector, T; $A$ - vector magnetic potential, $\mathrm{Wb} / \mathrm{m}$.

$$
J=\sigma E+j \omega D+J_{e}
$$

where $\sigma$ - electrical conductivity, S/m; E electric field strength vector, $\mathrm{V} / \mathrm{m} ; D$ - electric displacement vector, $\mathrm{C} / \mathrm{m}^{2} ; J_{e}$ - external current density, $\mathrm{A} / \mathrm{m}^{2}$.

The boundary condition necessary to achieve the tangential component of the magnetic potential equal to zero at the boundary of the model is achieved according to the equation: 


$$
n \times A=0
$$

where $n$-tangential component of the magnetic potential, $\mathrm{N}$. The magnetization of the ferromagnetic rotor is given as an effective B-H curve is a local linear relationship between the magnetic field density $B$ and the magnetic field strength $H$ is determined by the ratio:

$$
B=f_{\text {eff }}(|H|) \frac{H}{|H|}
$$

As a current source in the model multi-turn stator windings are used, fig. 2. The windings provide an external current density in the direction of the conductors according to the equation:

$$
J_{e}=\frac{N I_{\text {coil }}}{A} e_{\text {coil }}
$$

where $N$ - the number of turns in the winding; $A$ - total cross-sectional area of the winding domain, $\mathrm{m}^{2} ; I_{\text {coil }}$ - current, A; $e_{\text {coil }}-$ vector variable to visualize the direction of the turns in the winding.

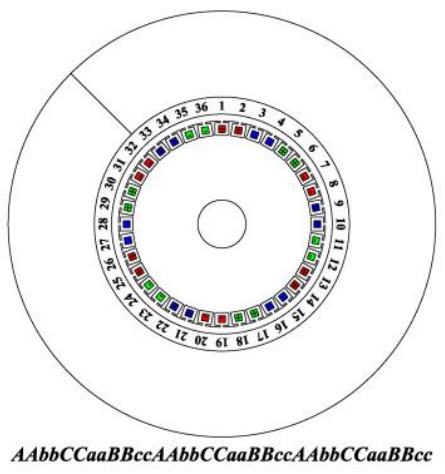

Fig. 2. Stator winding diagram

The heating simulation of the ferromagnetic rotor of a twin-screw electromechanical hydrolyser is realized by using the physics of magnetic fields, heat transfer in solids and multiphysical communication electromagnetic heating in the frequency-transition region of the study. The heat exchange equation corresponds to the differential form of Fourier's law, which may contain such extensions as a heat source:

$$
\begin{gathered}
d_{z} \rho C_{p} \frac{\partial T}{\partial t}+d_{z} \rho C_{p} u \cdot \nabla T+\nabla \cdot q= \\
=d_{z} Q+q_{0}+d_{z} Q_{\text {ted }}
\end{gathered}
$$

where $d_{z}$ - the thickness of the domain in the non-planar direction, $\mathrm{m} ; \rho-$ density, $\mathrm{kg} / \mathrm{m}^{3} ; C_{p}-$ specific heat at constant pressure, $\mathrm{J} /(\mathrm{kg} \cdot \mathrm{K}) ; T$ temperature, $\mathrm{K} ; t$ - time, $\mathrm{s} ; u$ - velocity vector, $\mathrm{m} / \mathrm{s} ; q$ - heat conductive flow, $\mathrm{W} / \mathrm{m}^{2} ; Q$ - heat source, $\mathrm{W} / \mathrm{m}^{3} ; q_{0}$ - internal heat flux, $\mathrm{W} / \mathrm{m}^{2} ; Q_{\text {ted }}-$ thermoelastic damping, $\mathrm{W} / \mathrm{m}^{3}$.

$$
q=-d_{z} k \nabla T
$$

where $k$-thermal conductivity, $\mathrm{W} /(\mathrm{m} \cdot \mathrm{K})$.

Thermal insulation at the outer boundary of the model is determined from the equation:

$$
-n \cdot q=0
$$

where $n$-refractive index.

The heat flux from the surface of the ferromagnetic rotor and its blades is determined by the equation:

$$
\begin{gathered}
-n \cdot q=d_{z} q_{0} \\
q_{0}=h\left(T_{e x t}-T\right)
\end{gathered}
$$

where $h$ - heat transfer coefficient, $\mathrm{W} /\left(\mathrm{m}^{2} \cdot \mathrm{K}\right)$; $T_{\text {ext }}$ - outside temperature, $\mathrm{K}$.

The radiation from the model surface to the environment is determined from the equation:

$$
\text { - } n \cdot q=d_{z} \varepsilon \sigma\left(T_{a m b}^{4}-T^{4}\right)
$$

where $\varepsilon$ - surface emissivity; $\sigma$ - StefanBoltzmann constant, $\mathrm{W} /\left(\mathrm{m}^{2} \cdot \mathrm{K}^{4}\right) ; T_{a m b}-$ ambient temperature, $\mathrm{K}$.

The multiphysical connection of electromagnetic heating is realized according to the following expressions:

$$
\rho C_{p} \frac{\partial T}{\partial t}+\rho C_{p} u \cdot \nabla T=\nabla \cdot(k \nabla T)+Q_{e}
$$

where $Q_{e}-$ electromagnetic heat source, $\mathrm{W} / \mathrm{m}^{3}$.

$$
Q_{e}=Q_{r h}+Q_{m l}
$$

where $Q_{r h}-$ resistive losses, $\mathrm{W} / \mathrm{m}^{2} ; Q_{m l}-$ magnetic losses, $\mathrm{W} / \mathrm{m}^{2}$.

$$
\begin{gathered}
Q_{r h}=\frac{1}{2} \operatorname{Re}\left(J \cdot E^{*}\right) \\
Q_{m l}=\frac{1}{2} \operatorname{Re}\left(i \omega B \cdot H^{*}\right)
\end{gathered}
$$

where Re - Reynolds number; $E^{*}$ - vector of electric field strength at a given frequency at a certain point in time, $\mathrm{V} / \mathrm{m} ; H^{*}-$ the vector of the magnetic field strength at a given frequency at a certain point in time, $\mathrm{A} / \mathrm{m}$.

The geometry of the ferromagnetic rotor is shown in Fig. 3. Its grid was created as a grid under the control of a software environment in accordance with the boundary conditions adopted in physical and multiphysical interfaces. The grid statistics are given in the table. 1 . 


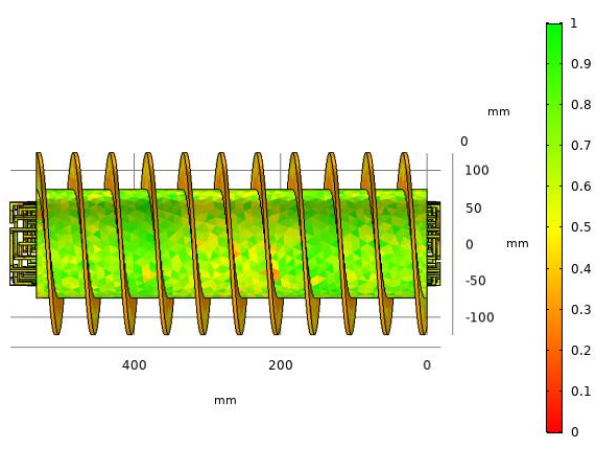

Fig. 3. Three-dimensional image of the finite element grid of the model

Since multiphysics modelling is a complex task that requires a significant amount of resources, thermal heating is modelled for the cross-section of the ferromagnetic rotor, Fig. 4. The grid parameters for the cross-section of the geometry are given in the table. 1 .

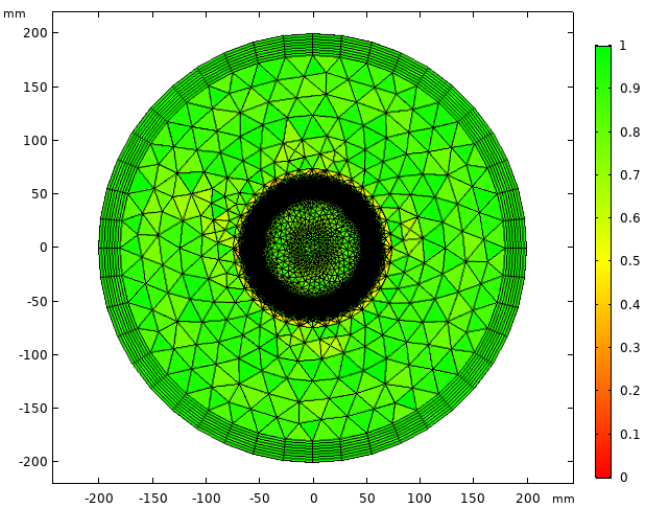

Fig. 4. Spatial distribution of a finite element grid

Table 1

Finite element grid parameters for the geometry of the ferromagnetic rotor

\begin{tabular}{|l|c|c|}
\hline \multicolumn{3}{|c|}{ Selected parameters } \\
\hline Grid parameters & $\begin{array}{c}\text { Ferromagnetic } \\
\text { rotor }\end{array}$ & $\begin{array}{c}\text { Rotor } \\
\text { cross- } \\
\text { section }\end{array}$ \\
\hline Tetrahedra & 309390 & - \\
\hline Triangles & 71510 & 86388 \\
\hline $\begin{array}{l}\text { Boundary ele- } \\
\text { ments }\end{array}$ & 23529 & 4820 \\
\hline Vertex elements & 2736 & 454 \\
\hline $\begin{array}{l}\text { The minimum } \\
\text { quality of the } \\
\text { element }\end{array}$ & 0.0011 & 0.318 \\
\hline $\begin{array}{l}\text { The average } \\
\text { quality of the } \\
\text { element }\end{array}$ & 0.464 & 0.869 \\
\hline $\begin{array}{l}\text { Element/volume } \\
\text { ratio }\end{array}$ & $1.054 \mathrm{E}-6$ & $4.946 \mathrm{E}-4$ \\
\hline Grid vol. / area & $8.751 \mathrm{E} 7 \mathrm{~mm}^{2}$ & $82440 \mathrm{~mm}^{2}$ \\
\hline
\end{tabular}

The simulation was performed for the electromagnetic system of the ferromagnetic rotor with the following parameters which are presented in the table. 2 .

Table 2

Parameters of the electromagnetic system on one stator of one ferromagnetic rotor

\begin{tabular}{|l|c|}
\hline \multicolumn{2}{|c|}{ Selected parameters } \\
\hline Power & $1,5 \mathrm{~kW}$ \\
\hline Rated voltage & $120 \mathrm{~V}$ \\
\hline Rated current & $12,5 \mathrm{~A}$ \\
\hline Frequency & $50 \mathrm{~Hz}$ \\
\hline Time range & $30 \mathrm{~min}$ \\
\hline
\end{tabular}

\section{Simulation results and discussion}

In fig. 5 shows a three-dimensional image of the magnetic field distribution density on the surface of the ferromagnetic rotor. From fig. 1 it is seen that the stators are placed separately along the axis of the hydrolyser, which is a condition for creating a stable zone with a cyclic level of magnetic field intensity. From the simulation results it is noticeable that within the length of the stator package, the average value of the magnetic field distribution density on the surface of the ferromagnetic rotor is $0.5 \mathrm{~T}$. Within the gap between the stators of the ferromagnetic rotor, this value is $0.15 \mathrm{~T}$.

The result of the calculation of the electromagnetic problem is a spatial image of the bulk density of electrical losses (Fig. 6), which is necessary to construct an image of the thermal field distribution of the ferromagnetic rotor. Graphical dependences of current density which are constructed on a curve along the screw winding on a surface of a ferromagnetic rotor and on the top face of a screw winding of a ferromagnetic rotor are shown in fig. 7,8 .

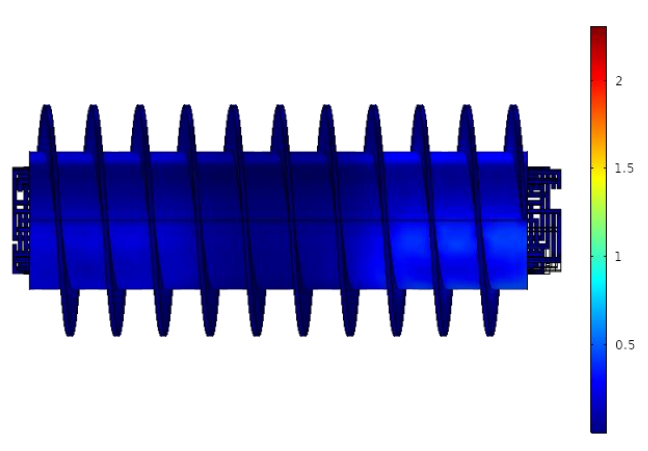

Fig. 5. Three-dimensional image of the magnetic field distribution density on the surface of the ferromagnetic rotor, $\mathrm{T}$

The highest density of electrical losses is observed on the inner surface of the ferromagnetic rotor. To more accurately estimate the density of electrical losses on the outer surface, the spatial integra- 
tion of the geometry of the ferromagnetic rotor was performed and it was found that the average value of the density of electrical losses is $6232.5 \mathrm{~W} / \mathrm{m}$ at a frequency $f=50 \mathrm{~Hz}$.

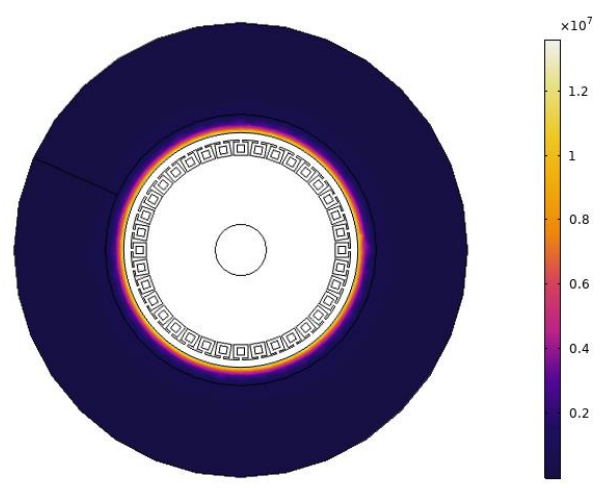

Fig. 6. Spatial representation of the bulk density of electrical losses, $\mathrm{W} / \mathrm{m}^{3}$

The results of modeling the thermal problem are presented in Fig. 9, 10. The simulation was performed under the condition that both stators of the ferromagnetic rotor operate in the motor mode - the rotating magnetic field of the stators moves in the same direction.

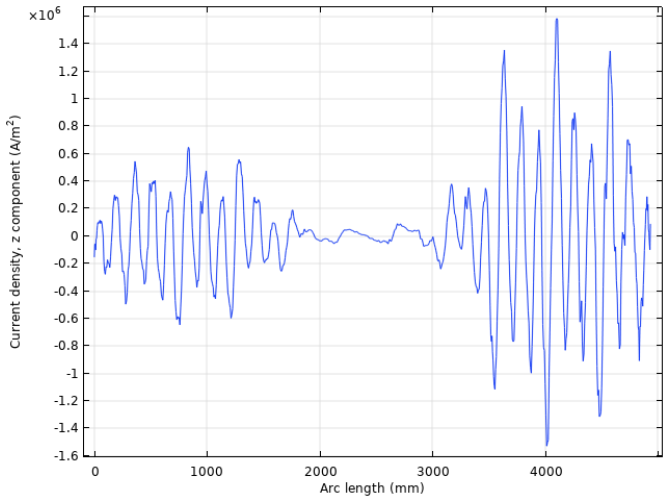

Fig. 7. The graph of current density is constructed along the curve laid in the direction of screw winding on a surface of a ferromagnetic rotor, $\mathrm{A} / \mathrm{m}^{2}$

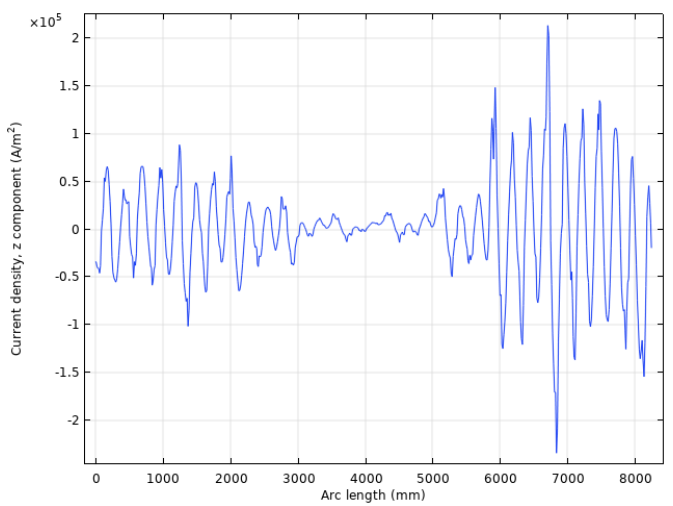

Fig. 8. The graph of current density is constructed along the curve laid on the top face of the screw winding of a ferromagnetic rotor, $\mathrm{A} / \mathrm{m}^{2}$
From fig. 9, 10 it is seen that the maximum temperature of the ferromagnetic rotor is $211.83{ }^{\circ} \mathrm{C}$, the minimum $187.25^{\circ} \mathrm{C}$, respectively. As mentioned earlier, for hydrothermal hydrolysis it is necessary to reach a temperature of $180-230^{\circ} \mathrm{C}$ at different stages of the process.

From [16] it is known that during heating keratin raw materials go through two stages. In the first stage, in the temperature range of $25-180{ }^{\circ} \mathrm{C}$, moisture evaporates from the material. In the second stage, $180-230{ }^{\circ} \mathrm{C}$, there is a partial decomposition of the keratin structure. In this range, thermal denaturation of peptide bonds and dehydration of the protein structure occur. From fig. 10 it is seen that the ferromagnetic rotor is heated to the temperature required for hydrothermal hydrolysis in 25 minutes. Further heating can be regulated by switching on one of the stators in the brake mode - the rotating magnetic field of the stator in the brake mode moves in the opposite direction to the magnetic field of the stator in the engine mode and using additional cooling.

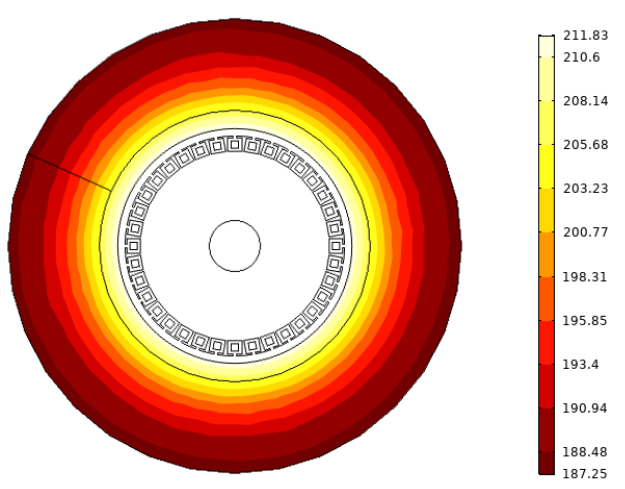

Fig. 9. Spatial representation of the temperature of the ferromagnetic rotor, ${ }^{\circ} \mathrm{C}$

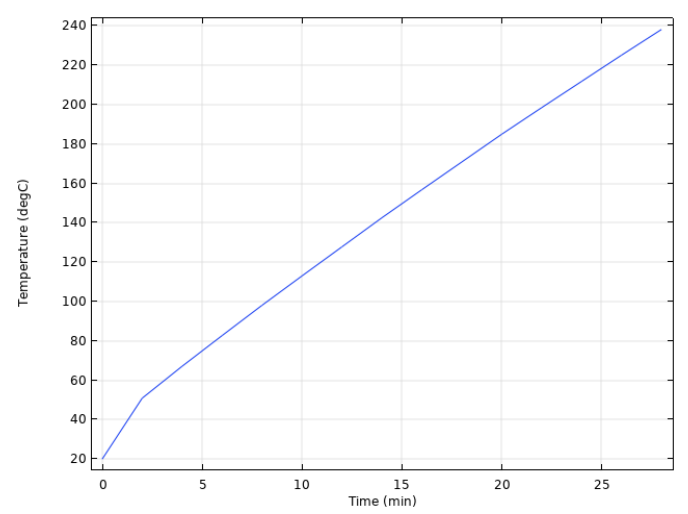

Fig. 10. The temperature chart of the ferromagnetic rotor during its operation time - 30 minutes

\section{Conclusion}

The proposed method of numerical analysis of thermal processes of a twin-screw electromechanical hydrolyser allows determining the parameters of the system, conducting their technical and economic 
evaluation in the future and optimizing the system in accordance with the requirements of the technological process at certain stages of raw material processing.

According to the simulation results, it is established that the ferromagnetic rotor of the twin-screw electromechanical hydrolyser will reach the temperature required for the hydrolysis of down-feather raw materials in 25 minutes.

The electromagnetic and thermal characteristics obtained in the work create conditions for further development of intelligent control algorithms for twin-screw electromechanical hydrolyser.

\section{Acknowledgment}

Publication with the support of the Ministry of Education and Science of Ukraine under the contract № 110/21-pr-2020 for work on the creation of scientific and technical products on "Development of electrotechnological complex with a hybrid energy supply system for processing poultry by-products into fuel, organic feed and fertilizers".

\section{References}

1. Salminen, E., Rintala, J. (2002) "Anaerobic digestion of organic solid poultry slaughterhouse waste - a review", Bioresource Technology, 83(1), pp. 13-26, doi:10.1016/S0960-8524(01)00199-7

2. Davidson, I. (2009) "Diverse Uses of Feathers with Emphasis on Diagnosis of Avian Viral Infections and Vaccine Virus Monitoring", Revista Brasileira de Ciência Avícola, 11(3), pp. 139-148, doi:10.1590/S1516-635X2009000300001

3. Luo, T., Hao, S., Chen, X., Wang, J., Yang, Q., Wang, Y., Weng, Y., Wei, H., Zhou, J., Wang, B. (2016) "Development and assessment of kerateine nanoparticles for use as a hemostatic agent", $M a$ ter Sci Eng C Mater Biol Appl, 63, pp. 352-358, doi:10.1016/j.msec.2016.03.007

4. Nurdiawati, A., Nakhshiniev, B., Nuran Zaini, I., Saidov, N., Takahashi, F., Yoshikawa, K. (2017) "Characterization of potential liquid fertilizers obtained by hydrothermal treatment of chicken feathers", Environmental Progress \& Sustainable Energy, 37(1), pp. 375-382, doi:10.1002/ep.12688

5. Wang, B., Yang, W., McKittrick, J., André Meyers, M. (2016) "Structure, mechanical properties, occurrence in biological organisms, and efforts at bioinspiration", Progress in Materials Science, 76, pp. 229-318, doi:10.1016/j.pmatsci.2015.06.001

6. Zaini, I. N., Novianti, S., Nurdiawati, A., Irhamna, A. R., Aziz, M., Yoshikawa, K. (2017) "Investigation of the physical characteristics of washed hydrochar pellets made from empty fruit bunch", Fuel Processing Technology, 160, pp. 109-120, doi:10.1016/j.fuproc.2017.02.020
7. Mohamad Mazlan, M., Talib, R. A., Mail, N. F., Taip, F. S., Chin, N. L., Sulaiman, R., Shukri, R., Mohd Nor, M. Z. (2019) "Effects of extrusion variables on corn-mango peel extrudates properties, torque and moisture loss", International Journal of Food Properties, 22, pp.54-70, doi:10.1080/10942912.2019.1568458

8. Singha, P., Muthukumarappan, K. (2016) "Effects of processing conditions on the system parameters during single screw extrusion of blend containing apple pomace", The Journal of Food Process Engineering, 40(4), pp. 1-11, doi:10.1111/jfpe. 12513

9. Feng, C., Li, Z., Wang, Z., Wang, B., Wang, Z. (2019) "Optimizing torque rheometry parameters for assessing the rheological characteristics and extrusion processability of wood plastic composites", Journal of Thermoplastic Composite Materials, 32(1), pp. 123-140, doi:10.1177/0892705717744828

10.Campuzano, F., Brown, R. C., Daniel Martínez, J. (2019) "Auger reactors for pyrolysis of biomass and wastes", Renewable and Sustainable Energy Reviews, 102, pp. 372-409, doi:10.1016/j.rser.2018.12.014

11.Qi, F., Mba Wright, M. (2020) “A DEM modeling of biomass fast pyrolysis in a double auger reactor", International Journal of Heat and Mass Transfer, 150 , doi:10.1016/j.ijheatmasstransfer.2020.119308

12. Funke, A., Grandl, R., Ernst, M., Dahmen, N. (2018) "Modelling and improvement of heat transfer coefficient in auger type reactors for fast pyrolysis application", Chemical Engineering and Processing - Process Intensification, 130, pp. 67-75, doi:10.1016/j.cep.2018.05.023

13. Mushtruk, M., Gudzenko, M., Palamarchuk, I., Vasyliv, V., Slobodyanyuk, N., Kuts, A., Nychyk, O., Salavor, O., Bober, A. (2020) "Mathematical modeling of the oil extrusion process with pregrinding of raw materials in a twin-screw extruder", Potravinarstvo Slovak Journal of Food Sciences, 14, pp. 937-944, doi: 10.5219/1436

14.Zablodskiy, M., Kovalchuk, S. (2020) "The main aspects of the technology of processing keratin raw materials under the influence of a magnetic field", 2020 IEEE KhPI Week on Advanced Technology (KhPIWeek), Kharkiv, Ukraine, pp. 278-282, doi:10.1109/KhPIWeek51551.2020.9250153

15.Zablodskiy, M., Plyugin, V. (2014) "Simulation of thermal processes in the screw electromechanical transformers using Matlab/Simulink" ["Matematicheskoye modelirovaniye teplovykh protsessov $\mathrm{v}$ shnekovom elektromekhanicheskom preobrazovatele s ispol'zovaniyem Matlab / Simulink"], Vestnik Nats. tekhn. un-ta "KHPI": sb. nauch. tr. Temat. vyp. : Elektricheskiye mashiny $i$ 
elektromekhanicheskoye preobrazovaniye energii. Khar'kov: NTU "KHPI", 38(1081), pp. 90-97

16.Tesfaye, T., Sithole, B., Ramjugernath, D., Mokhothu, T. (2018) "Valorisation of chicken feath- ers: Characterisation of thermal, mechanical and electrical properties", Sustainable Chemistry and Pharmacy, 9, pp. 27-34, doi: 10.1016/j.scp.2018.05.003

\title{
ЧИСЕЛЬНИЙ АНАЛІЗ ТЕПЛОВИХ ПРОЦЕСІВ В ДВОШНЕКОВОМУ ЕЛЕКТРОМЕХАНІЧНОМУ ГІДРОЛІЗЕРІ ДЛЯ ПЕРЕРОБКИ ПОБІЧНИХ ПРОДУКТІВ ПТАХІВНИЦТВА
}

\author{
С. І. Ковальчук ${ }^{1}$, М. М. Заблодський ${ }^{1}$, А. В. Жильцов ${ }^{1}$, Р. М. Чуснко ${ }^{1}$, В. Ю. Грицюк ${ }^{2}$ \\ ${ }^{1}$ Національний університет біоресурсів і природокористування Украӥни \\ ${ }^{2}$ Харківський національний університет радіоелектроніки
}

\begin{abstract}
Анотація. Промислова переробка побічних продуктів птахівнищтва - важливе завдання, що вимагає значних витрат енергії. Технологія гідротермічної переробки в двошнековому електромеханічному гідролізері покликана вирішити проблему високих енерговитрат на переробку. Зважаючи на складність конструкиії двошнекового електромеханічного гідролізера доцільно мати повне уявлення про його характеристики ще на етапі попереднього проектування. У статті представлена кінцевоелементна модель двуошнекового електромеханічного гідролізера для чисельного аналізу теплового стану обладнання. Математична модель побудована з використанням фізики електромагнітних полів, теплообміну в твердих тілах і мультифізичного зв'язку - електромагнітний нагрів в частотноперехідної області дослідження. Фізика магнітних полів описується рівняннями Максвелла. Рівняння теплопередачі відповідають диференціальної формі закону Фур'є. Результати моделювання представлені у вигляді тривимірного зображення щільності розподілу магнітного поля, просторових зображень температури, об'ємної щеільності електричних втрат, графічних залежностей температури і щүільності струму. 3 результатів моделювання видно, що в межах довжини пакета статора середнє значення щільності розподілу магнітного поля на поверхні феромагнітного ротора становить 0,5 Тл. У зазорі між статорами феромагнітного ротора це значення становить 0,15 Тл. Максимальне значення щільності струму на поверхні феромагнітного ротора становить $1,5 \cdot 10^{6} \mathrm{~A} / \mathrm{M}^{2}$, мінімальне $0,1 \cdot 10^{6} \mathrm{~A} / \mathrm{m}^{2}$, для верхньої межі гвинтовий обмотки феромагнітного ротора иі значення становлять $2,1 \cdot 10^{5} \mathrm{~A} / \mathrm{M}^{2}$ і $0,6 \cdot 10^{5} \mathrm{~A} / \mathrm{M}^{2}$ відповідно. Максимальна температура феромагнітного ротора протягом 30 хвилин моделювання становить $211,83{ }^{\circ} \mathrm{C}$, мінімальна 187,25 ${ }^{\circ} \mathrm{C}$ відповідно. 3 а результатами моделювання встановлено, що феромагнітний ротор двошнекового електромеханічного гідролізера досягне температури, необхідної для гідролізу пухо-пір'яного сировини, за 25 хвилин.
\end{abstract}

Ключові слова: кератинова сировина, гідротермічний гідроліз, рівняння Максвелла, закон Фур'є, магнітна індукція, тепловий розрахунок

\section{ЧИСЛЕННЫЙ АНАЛИЗ ТЕПЛОВЫХ ПРОЦЕССОВ В ДВУХШНЕКОВОМ ЭЛЕКТРОМЕХАНИЧЕСКОМ ГИДРОЛИЗЕРЕ ДЛЯ ПЕРЕРАБОТКИ ПОБОЧНЫХ ПРОДУКТОВ ПТИЦЕВОДСТВА}

\author{
С. И. Ковальчук ${ }^{1}$, Н. Н. Заблодський ${ }^{1}$, А. В. Жильцов ${ }^{1}$, Р. Н. Чуенко ${ }^{1}$, В. Ю. Грицюк ${ }^{2}$ \\ ${ }^{1}$ Национальный университет биоресурсов и природопользования Украины \\ ${ }^{2}$ Харьковский национальный университет радиоэлектроники
}

\begin{abstract}
Аннотация. Получено пространственное изображение температуры путем математического моделирования физики электромагнитных полей, теплопередачи в твердых телах и мультифизической связи - электромагнитный нагрев в частотно-переходной области исследования. Модель построена по методу конечных-элементов. Результаты моделирования представлены в виде трехмерного изображения плотности распределения магнитного поля, пространственных изображений температуры, объемной плотности электрических потерь, графических зависимостей температуры и плотности тока.

Ключевые слова: кератиновое сырье, гидротермический гидролиз, уравнение Максвелла, закон Фурье, магнитная индукиия, тепловой расчет
\end{abstract}

Received 15.04.2021 

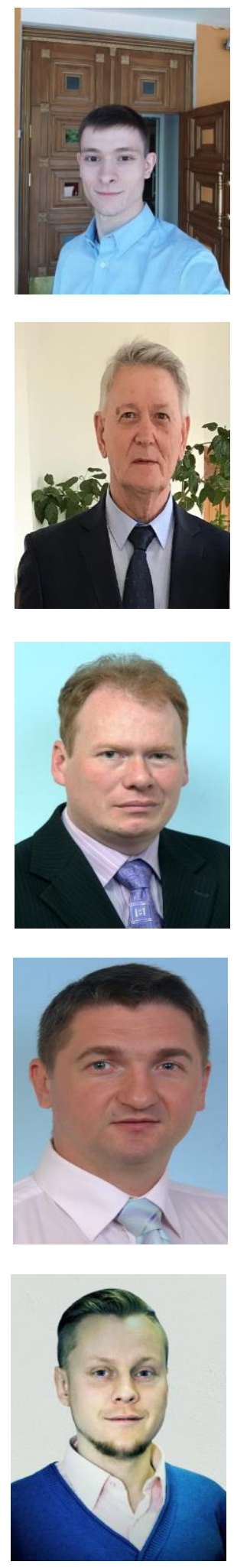

Stanislav Kovalchuk, The National University of Life and Environmental Sciences of Ukraine, graduate student, Department of Electrical Engineering, Electromechanics and Electrotechnology, Heroiv Oborony Str.12, Kyiv, Ukraine, 03041

Станіслав Ігорович Ковальчук, Національний університет біоресурсів і природокористування України, аспірант кафедри електротехніки, електромеханіки та електротехнологій. 03041, м. Київ, вул. Героїв Оборони, 12, Україна, E-mail: kovalchuk@it.nubip.edu.ua, тел. +38-093-528-38-94

ORCID ID: 0000-0002-1194-3464

Nikolay Zablodskiy, The National University of Life and Environmental Sciences of Ukraine, Dr. of Science, Professor, Department of Electrical Engineering, Electromechanics and Electrotechnology, 03041, Kyiv, Heroiv Oborony Str.12, Ukraine

Микола Миколайович Заблодський, Національний університет біоресурсів і природокористування України, доктор технічних наук, професор кафедри електротехніки, електромеханіки та електротехнологій. 03041, м. Київ, вул. Героїв Оборони, 12, Україна, E-mail: zablodskiynn@gmail.com, тел. +38-044-527-87-84

ORCID ID: 0000-0001-8889-8158

Andrii Zhyltsov, The National University of Life and Environmental Sciences of Ukraine, Dr. of Science, Professor, Head of the Department of Electrical Engineering, Electromechanics and Electrotechnology, 03041, Kyiv, Heroiv Oborony Str.12, Ukraine

Андрій Володимирович Жильцов, Національний університет біоресурсів і природокористування України, доктор технічних наук, професор, завідувач кафедри електротехніки, електромеханіки та електротехнологій. 03041, м. Київ, вул. Героїв Оборони, 12, Україна, E-mail: zhylcov@ nubip.edu.ua, тел. +38-044-527-87-84

ORCID ID: 0000-0002-1688-7879

Roman Chuenko, The National University of Life and Environmental Sciences of Ukraine, Ph.D., Associate Professor, Department of Electrical Engineering, Electromechanics and Electrotechnology, 03041, Kyiv, Heroiv Oborony Str.12, Ukraine

Роман Миколайович Чуєнко, Національний університет біоресурсів і природокористування України, кандидат технічних наук, доцент кафедри електротехніки, електромеханіки та електротехнологій. 03041, м. Київ, вул. Героїв Оборони, 12, Україна, E-mail: roman_chuenko@ukr.net, тел. +38-044-527-87-84

ORCID ID: 0000-0002-9339-9764

Volodymyr Gritsyuk, Kharkiv National University of Radio Electronics, Ph.D., Associate Professor, Department of Computer-Integrated Technologies, Automation and Mechatronics, 61166, Kharkiv, Nauky Ave. 14, Ukraine

Володимир Юрісвич Грицюк, Харківський національний університет радіоелектроніки, кандидат технічних наук, доцент кафедри кафедри комп'ютерноінтегрованих технологій, автоматизації та мехатроніки (КІТАМ). 61166, м. Харків, пр. Науки, 14, Україна, E-mail: volodymyr.hrytsiuk@ nure.ua, тел. +38-057-702-14-86

ORCID ID: 0000-0003-0156-7589 